\title{
Muricauda olearia sp. nov., isolated from crude-oil- contaminated seawater, and emended description of the genus Muricauda
}

Correspondence
Byung C. Cho
bccho@snu.ac.kr

The genus Muricauda, a member of the family Flavobacteriaceae, was established by Bruns et al. (2001) with Muricauda ruestringensis as the type species. Some cells of this non-motile bacterium, which was isolated from intertidal sediment, displayed long and relatively thick appendages. Three other Muricauda species with similar appendages were subsequently isolated from a salt lake (Muricauda flavescens and Muricauda aquimarina; Yoon et al., 2005) and tidal flat sediment (Muricauda lutimaris; Yoon et al., 2008). In this study, a marine bacterium isolated from crude-oil-contaminated seawater was subjected to a polyphasic taxonomic analysis and allocated to the genus Muricauda.

Crude-oil-contaminated seawater was collected from the west coast of Korea. An aliquot $(50 \mu \mathrm{l})$ of seawater was spread on marine agar 2216 (MA; Difco) and incubated under aerobic conditions at $30{ }^{\circ} \mathrm{C}$ for a week. Strain

The GenBank/EMBL/DDBJ accession number for the 16S rRNA gene sequence of strain CL-SS4 ${ }^{\top}$ is EU888117.
CL-SS4 ${ }^{\mathrm{T}}$ was isolated by streaking on fresh MA and subsequent incubation. The purification procedure was repeated four times. The strain was maintained on MA at $30{ }^{\circ} \mathrm{C}$ and preserved in marine broth 2216 (MB; Difco) supplemented with $30 \%(\mathrm{v} / \mathrm{v})$ glycerol at $-80{ }^{\circ} \mathrm{C}$.

For 16S rRNA gene amplification by PCR, DNA was extracted from a single colony by using a boiling method (Englen \& Kelley, 2000). The crude extract served as the DNA template for amplification, which included Taq DNA polymerase (Promega) and primers 27F and 1492R (Lane, 1991). The PCR product was purified by using an AccuPrep PCR Purification kit (Bioneer) and direct sequence determination of the purified 16S rRNA gene was performed with an Applied Biosystems automated sequencer (ABI 3730XL) at Macrogen, Seoul. The almostcomplete 16S rRNA gene sequence of strain CL-SS4 ${ }^{\mathrm{T}}$ (1417 bp) was obtained and compared with available $16 \mathrm{~S}$ rRNA gene sequences in GenBank using BLASTN searches (Altschul et al., 1990). The sequence of strain CL-SS4 ${ }^{\mathrm{T}}$ was manually aligned with those of related species in the family 
Flavobacteriaceae, obtained from the GenBank and Ribosomal Database Project II (Cole et al., 2007) databases, using known $16 \mathrm{~S}$ rRNA secondary-structure information. Phylogenetic trees were obtained by using the neighbourjoining (Saitou \& Nei, 1987), maximum-parsimony (Fitch, 1971) and maximum-likelihood (Felsenstein, 1981) methods. An evolutionary distance matrix for the neighbourjoining method was generated according to the model of Jukes \& Cantor (1969). The robustness of tree topologies was assessed by bootstrap analyses based on 1000 replications for the neighbour-joining and maximumparsimony methods and 100 replications for the maximum-likelihood method. Alignment analysis was carried out using the jPHYDIT program (Jeon et al., 2005), and phylogenetic analyses were carried out using MEGA4 (Tamura et al., 2007) and PAUP 4.0 (Swofford, 1998). Likelihood parameters were estimated by using the hierarchical ratio test in MODELTEST, version 3.04 (Posada \& Crandall, 1998).

Phylogenetic analyses based on the 16S rRNA gene sequence showed that strain $\mathrm{CL}-\mathrm{SS} 4^{\mathrm{T}}$ belonged to the genus Muricauda in the family Flavobacteriaceae (Fig. 1). Strain CL-SS4 ${ }^{\mathrm{T}}$ was most closely related to M. aquimarina SW $-63^{\mathrm{T}} \quad(96.9 \%$ sequence similarity) and to other members of the genus Muricauda (95.7-96.5\% sequence similarity). The tree topologies inferred from the three tree-making algorithms showed that strain CL-SS4 ${ }^{\mathrm{T}}$ formed a coherent linage with the clade comprising recognized Muricauda species (Fig. 1). The relationship was supported by high bootstrap values (neighbourjoining, $100 \%$; maximum-parsimony, $98 \%$; and maximum-likelihood, $89 \%$ ). The low similarity value of less than $97 \%$ (Rosselló-Mora \& Amann, 2001) and the distinct phylogenetic position of strain CL-SS4 ${ }^{\mathrm{T}}$ indicated that the isolate represents a novel species of the genus Muricauda.

Morphological and physiological tests were performed as follows. Unless otherwise specified, all biochemical characteristics of strain CL-SS4 ${ }^{\mathrm{T}}$ and M. aquimarina KCCM $41646^{\mathrm{T}}$ were based on cultures grown on MA at $30{ }^{\circ} \mathrm{C}$. Except for ranges of temperature, $\mathrm{pH}$ and salinity for growth, fatty acids composition and genomic DNA G $+\mathrm{C}$ content, the other tests were performed with M. aquimarina $\mathrm{KCCM} 41646^{\mathrm{T}}$ as the reference strain. Gram-staining was performed as described by Smibert \& Krieg (1994). Flagellar and gliding motilities were assessed by using the hanging-drop method (Skerman, 1967) with cells grown in $\mathrm{MB}$ for 2 days. Cellular morphology and the presence of flagella and appendages were observed using transmission electron microscopy (EX2; JEOL). The presence of endospores was assessed by malachite green staining (Smibert \& Krieg, 1994). The presence of flexirubin-type pigments was assessed as described by Gosink et al. (1998). Anaerobic growth was checked on MA, MA supplemented with potassium nitrate $(0.1 \%, \mathrm{w} / \mathrm{v})$ or ZOF medium (Lemos et al., 1985) supplemented with agar (1.5\%) incubated in the GasPak anaerobic system (BBL) at $30{ }^{\circ} \mathrm{C}$ for 10 days. The temperature range for growth was examined on the basis of colony formation on MA incubated at temperatures ranging from 5 to $45^{\circ} \mathrm{C}$, with increments of $5{ }^{\circ} \mathrm{C}$. The $\mathrm{pH}$ range for growth was determined by assessing changes in $\mathrm{OD}_{600}$ over the incubation period (up to 7 days) in $\mathrm{MB}$ at $30{ }^{\circ} \mathrm{C}$. Prior to autoclaving, the $\mathrm{pH}$ was adjusted to $\mathrm{pH} 4-10$ with increments of $0.5 \mathrm{pH}$ unit using $1 \mathrm{M} \mathrm{NaOH}$ and $1 \mathrm{M} \mathrm{HCl}$. The $\mathrm{pH}$ was measured after autoclaving and cooling and

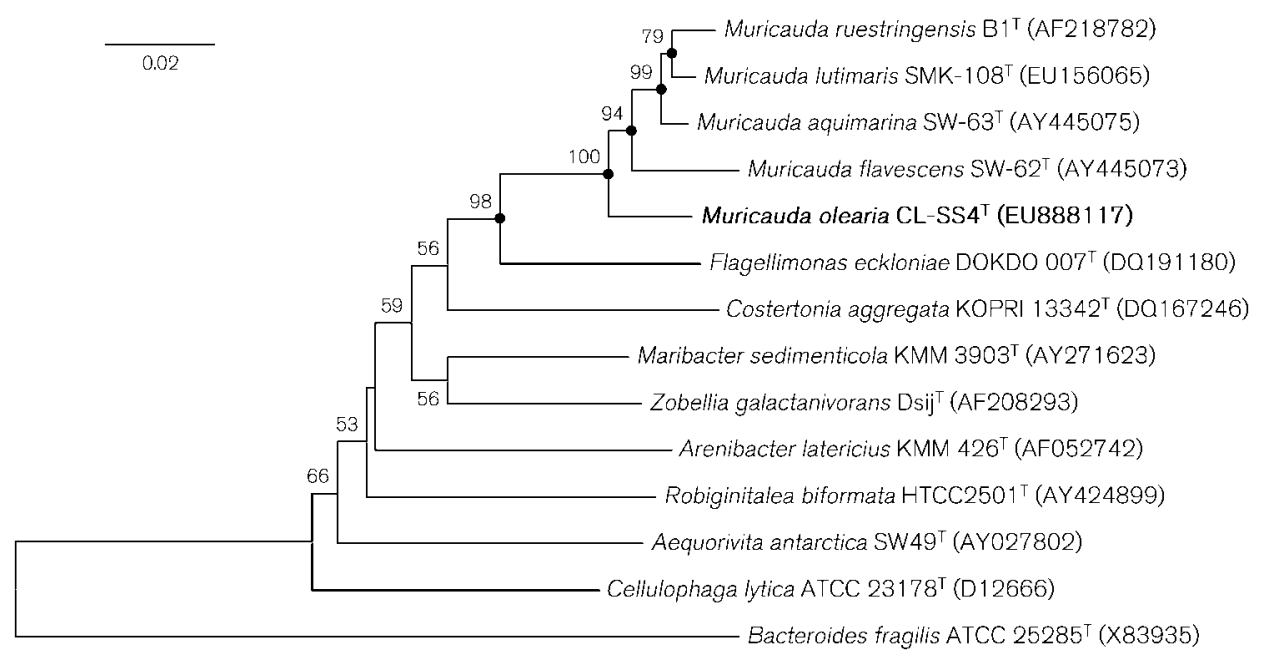

Fig. 1. Neighbour-joining phylogenetic tree derived from the $16 \mathrm{~S}$ rRNA gene sequences of strain $\mathrm{CL}-\mathrm{SS} 4^{\top}$ and related members in the family Flavobacteriaceae. The sequence of Bacteroides fragilis ATCC $25285^{\top}$ (X83935) was used as an outgroup. Bootstrap values from 1000 resamplings above $50 \%$ are shown at branch points. Solid circles indicate that the corresponding nodes were also recovered in the maximum-parsimony and the maximum-likelihood trees. Bar, 0.02 nucleotide substitution per site. 
the following $\mathrm{pH}$ values were used to measure the ability to grow: $\mathrm{pH} 4.1,4.7,5.2,5.9,6.4,6.8,7.2,7.7,8.1,8.5,8.9,9.4$ and 9.9. The tolerance of strain CL-SS4 ${ }^{\mathrm{T}}$ to sea salts (Sigma) or $\mathrm{NaCl}$ was determined by assessing changes in $\mathrm{OD}_{600}$ at $30{ }^{\circ} \mathrm{C}$ in ZoBell broth $\left(1^{-1}: 5 \mathrm{~g}\right.$ Bacto peptone, $1 \mathrm{~g}$ yeast extract, $0.1 \mathrm{~g}$ ferric citrate) supplemented with 0 $10 \%$ (with increments of $1 \%$ ) and 12 and $15 \%(\mathrm{w} / \mathrm{v})$ of sea salts or $\mathrm{NaCl}$.

The tests for oxidase and catalase activities and hydrolysis of casein, hypoxanthine, tyrosine and xanthine were performed according to Smibert \& Krieg (1994). Nitrate reduction and hydrolysis of gelatin, Tweens 20, 40, 60 and 80 and urea were tested according to Hansen \& Sørheim (1991). $\mathrm{H}_{2} \mathrm{~S}$ production was tested as described by Bruns et al. (2001). In addition, other enzyme activities were assayed using the API ZYM kit (bioMerieux) according to the manufacturer's instructions, except that the cell suspension was prepared using artificial seawater $\left(1^{-1}: 24 \mathrm{~g} \mathrm{NaCl}\right.$, $10.9 \mathrm{~g} \mathrm{MgCl}_{2} .6 \mathrm{H}_{2} \mathrm{O}, 4 \mathrm{~g} \mathrm{Na}_{2} \mathrm{SO}_{4}, 1.5 \mathrm{~g} \mathrm{CaCl}_{2} .2 \mathrm{H}_{2} \mathrm{O}, 0.7 \mathrm{~g}$ $\mathrm{KCl}, 0.2 \mathrm{~g} \mathrm{NaHCO}_{3}, 0.1 \mathrm{~g} \mathrm{KBr}, 0.027 \mathrm{~g} \mathrm{H}_{3} \mathrm{BO}_{3}, 0.03 \mathrm{~g}$ $\mathrm{SrCl}_{2} \cdot 6 \mathrm{H}_{2} \mathrm{O}, 0.003 \mathrm{~g} \mathrm{NaF}$; Lyman \& Fleming, 1940). Acid production from carbohydrates was tested as described by Lemos et al. (1985). Carbon utilization was tested using a basal broth medium supplemented with yeast extract (Bruns et al., 2001) containing $0.2 \%$ carbon source. A negative control without a carbon source was also employed and did not show any growth. Growth was monitored by $\mathrm{OD}_{600}$ using a spectrophotometer (Ultraspec 2000; Pharmacia Biotech) for 15 days. Resistance to antibiotics was determined on MA incubated at $30{ }^{\circ} \mathrm{C}$ for 7 days by using the disc-diffusion plate method (Bauer et al., 1966).

The phenotypic characteristics of strain CL-SS4 ${ }^{\mathrm{T}}$ are given in the species description and Table 1. The following phenotypic characteristics were unique to strain CL-SS4 ${ }^{\mathrm{T}}$ : inability to produce $\alpha$-glucosidase and to utilize fructose and mannose as sole carbon source, and ability to utilize glutamate and pyruvate as sole carbon source and to produce acid from D-ribose (Table 1). Strain CL-SS4 ${ }^{\mathrm{T}}$ differed from its closest phylogenetic neighbour $M$. aquimarina by hydrolysis of gelatin, $\alpha$-chymotrypsin, $\beta$ glucosidase and trypsin activities and utilization of carbon substrates (Table 1).

The fatty acid methyl esters in whole cells of strain CL-SS4 ${ }^{\mathrm{T}}$ grown on $\mathrm{MA}$ at $30{ }^{\circ} \mathrm{C}$ for 3 days were analysed by gas chromatography according to the instructions of the Microbial Identification System at KCCM in Seoul. DNA was extracted by using the method of Marmur (1961). The genomic DNA G $+\mathrm{C}$ content was analysed by HPLC (HP 100; Hewlett Packard) and analysis of deoxyribonucleosides was performed as described by Mesbah et al. (1989). Lambda phage DNA was used as a standard. Isoprenoid quinone composition was determined according to Minnikin et al. (1984) and analysed by HPLC as described by Collins (1985), using M. aquimarina KCCM $41646^{\mathrm{T}}$ (Yoon et al., 2005) as the reference strain.
The major fatty acids of strain CL-SS4 ${ }^{\mathrm{T}}$ were iso- $\mathrm{C}_{17: 0} 3$ $\mathrm{OH}(20.5 \%)$, iso- $\mathrm{C}_{15: 0}(18.7 \%)$ and iso- $\mathrm{C}_{15: 1} \mathrm{G}(17.1 \%)$, and its detailed fatty acid composition is shown in Table 2. The fatty acid profile of strain CL-SS4 ${ }^{\mathrm{T}}$ was similar to those of type strains of the four recognized Muricauda species grown under the same conditions though in slightly different proportions (Table 2). The major menaquinone of strain CL-SS4 ${ }^{\mathrm{T}}$ was menaquinone-6 (MK-6) in line with the other Muricauda species (Yoon et al., 2005, 2008). These chemotaxonomic data supported the attribution of strain CL-SS4 ${ }^{\mathrm{T}}$ to the genus Muricauda (Bruns et al., 2001; Yoon et al., 2005, 2008). The DNA G + C content of strain CL-SS4 ${ }^{\mathrm{T}}$ was $50.7 \mathrm{~mol} \%$, a value significantly higher than the range reported for Muricauda species (Table 1).

Overall, the phenotypic data and phylogenetic inference obtained in this study indicate that strain CL-SS4 ${ }^{\mathrm{T}}$ should be assigned as representing a novel species of the genus Muricauda, for which the name Muricauda olearia sp. nov. is proposed. An emended description of the genus Muricauda is also proposed.

\section{Emended description of the genus Muricauda Bruns et al. 2001, emend. Yoon et al. 2005}

The description is as given by Bruns et al. (2001) and Yoon et al. (2005) with the following modifications. The DNA $\mathrm{G}+\mathrm{C}$ content is $41-51 \mathrm{~mol} \%$. The major isoprenoid quinone is MK-6.

\section{Description of Muricauda olearia sp. nov.}

Muricauda olearia (o.le.a'ri.a. L. fem. adj. olearia pertaining to oil, referring to its source of isolation).

Gram-staining-negative, strictly aerobic, non-motile and non-spore-forming rods approximately $0.3-0.4 \mu \mathrm{m}$ wide and 1.6-4.4 $\mu \mathrm{m}$ long. Appendages similar to those reported in other Muricauda species occur on some cells. After 3 days on MA at $30{ }^{\circ} \mathrm{C}$, colonies are yellow, circular and convex, and approximately $1 \mathrm{~mm}$ in diameter. Grows at $15-40{ }^{\circ} \mathrm{C}$ (optimum, $25-30{ }^{\circ} \mathrm{C}$ ) and at $\mathrm{pH} 5.2-9.4$ (optimum, pH 6.8-7.7). Growth occurs at 1-6\% (w/v) sea-salt concentration (optimum, 2-3\%), but no growth occurs in media containing only $\mathrm{NaCl}$. Flexirubin-type pigments are not produced. Positive for oxidase and catalase. Gelatin, tyrosine and Tweens 20, 40, 60 and 80 are hydrolysed, but casein, hypoxanthine, urea and xanthine are not. Negative for $\mathrm{H}_{2} \mathrm{~S}$ production and nitrate reductase. According to the API ZYM test, $N$-acetyl- $\beta$-glucosaminidase, acid and alkaline phosphatases, cystine arylamidase, esterase (C4), esterase lipase (C8), leucine arylamidase, naphthol-AS-BI-phosphohydrolase and valine arylamidase activities are present, but $\alpha$-chymotrypsin, $\alpha$-fucosidase, $\alpha$ and $\beta$-galactosidases, $\alpha$ - and $\beta$-glucosidases, $\beta$-glucuronidase, lipase (C14), $\alpha$-mannosidase and trypsin activities are absent. L-Arginine, cellobiose, glucose, glutamate, lactose, pyruvate, raffinose and sucrose are utilized as sole carbon sources, but acetate, alanine, benzoate, citrate, ethanol, 
Table 1. Differential characteristics of strain CL-SS4 ${ }^{\top}$ and other Muricauda species

Strains: 1, Muricauda olearia sp. nov. CL-SS4 ${ }^{\mathrm{T}}$ (data from this study); 2, M. aquimarina SW-63 ${ }^{\mathrm{T}}$ (Yoon et al., 2005, 2008 and this study); 3, M. lutimaris SMK-108 ${ }^{\mathrm{T}}$ (Yoon et al., 2008); 4, M. ruestringensis $\mathrm{B1}^{\mathrm{T}}$ (Bruns et al., 2001; Yoon et al., 2005); 5, M. flavescens SW- $62^{\mathrm{T}}$ (Yoon et al., 2005). All strains are positive for the following characteristics: presence of oxidase, $N$-acetyl$\beta$-glucosaminidase, alkaline phosphatase, cystine arylamidase, esterase lipase (C8), leucine arylamidase and valine arylamidase activities; hydrolysis of Tween 20 and tyrosine; utilization of cellobiose and sucrose; and acid production from cellobiose, D-fructose, D-glucose, lactose, D-mannose, raffinose, sucrose and trehalose. All strains are negative for the following characteristics: growth without $\mathrm{NaCl}$ and at $4{ }^{\circ} \mathrm{C}$; nitrate reduction and $\mathrm{H}_{2} \mathrm{~S}$ production; presence of $\alpha$-fucosidase, $\alpha$ - and $\beta$-galactosidases, $\beta$-glucuronidase, lipase (C14) and $\alpha$-mannosidase activities; hydrolysis of hypoxanthine, urea and xanthine; utilization of acetate, benzoate, citrate, ethanol, formate, mannitol, methanol and L-serine; and acid production from myo-inositol and D-mannitol. +, Positive; -, negative; w, weakly positive.

\begin{tabular}{|c|c|c|c|c|c|}
\hline Characteristic & 1 & 2 & 3 & 4 & 5 \\
\hline Facultative anaerobic growth & - & - & + & + & - \\
\hline Optimal growth temperature $\left({ }^{\circ} \mathrm{C}\right)$ & $25-30$ & $30-37^{*}$ & 30 & $20-30$ & $30-37$ \\
\hline Catalase activity & + & + & + & $-\dagger$ & + \\
\hline \multicolumn{6}{|l|}{ Hydrolysis of: } \\
\hline Casein & - & - & + & - & - \\
\hline Gelatin & + & - & + & - & - \\
\hline Tweens 40,60 and 80 & + & + & - & + & + \\
\hline \multicolumn{6}{|l|}{ Enzyme activity (API ZYM) } \\
\hline Acid phosphatase & + & + & + & + & - \\
\hline$\alpha$-Chymotrypsin & - & + & + & - & + \\
\hline Esterase (C4) & + & + & + & - & + \\
\hline$\alpha$-Glucosidase & - & + & + & + & + \\
\hline$\beta$-Glucosidase & - & + & + & + & - \\
\hline Naphthol-AS-BI-phosphohydrolase & + & + & + & + & - \\
\hline Trypsin & - & + & - & - & $\mathrm{w}$ \\
\hline \multicolumn{6}{|l|}{ Utilization of: } \\
\hline Alanine & - & - & - & + & - \\
\hline L-Arginine & $\mathrm{w}$ & - & - & + & - \\
\hline Fructose & - & + & + & + & + \\
\hline Glucose & + & + & + & - & + \\
\hline Glutamate & + & - & - & - & - \\
\hline Lactose & + & + & - & + & + \\
\hline Mannose & - & + & + & + & + \\
\hline Pyruvate & + & - & - & - & - \\
\hline Raffinose & + & + & - & + & + \\
\hline Succinate & - & + & - & + & + \\
\hline \multicolumn{6}{|l|}{ Acid production from: } \\
\hline L-Arabinose & - & - & + & + & - \\
\hline D-Galactose & - & - & + & + & - \\
\hline D-Ribose & + & - & - & - & - \\
\hline D-Xylose & - & - & - & + & - \\
\hline DNA G $+C$ content $(\mathrm{mol} \%)$ & 50.7 & $44.1^{\star}$ & 41.1 & 41 & 45.2 \\
\hline
\end{tabular}

${ }^{\star}$ Data from Yoon et al. (2005). For the other tests, congruent results were obtained from this study with Yoon et al. (2005, 2008). $\dagger$ Negative in Bruns et al. (2001) but positive in Yoon et al. (2005).

formate, fructose, mannitol, mannose, methanol, L-serine and succinate are not utilized. Acid is produced from cellobiose, D-fructose, D-glucose, lactose, D-mannose, raffinose, D-ribose, sucrose and trehalose, but not from Larabinose, D-galactose, myo-inositol, D-mannitol or Dxylose. Sensitive to ( $\mu \mathrm{g}$ per disc) ampicillin (6), cephalexin (20), gentamicin (6), kanamycin (20), mitomycin C (0.6), penicillin $G(6)$, polymyxin B (25), streptomycin (6) and vancomycin (20), but resistant to chloramphenicol (20), erythromycin (10), nalidixic acid (20) and tetracycline (20). Major cellular fatty acids are iso- $\mathrm{C}_{17: 0} 3-\mathrm{OH}$, iso$\mathrm{C}_{15: 0}$ and iso- $\mathrm{C}_{15: 1} \mathrm{G}$. The DNA G $+\mathrm{C}$ content of the type strain is $50.7 \mathrm{~mol} \%$.

The type strain, CL-SS4 $4^{\mathrm{T}}\left(=\mathrm{KCCM} 90075^{\mathrm{T}}=\mathrm{JCM} 15563^{\mathrm{T}}\right)$, was isolated from crude-oil-contaminated seawater from the west coast of Korea. 
Table 2. Cellular fatty acid composition (\%) of strain CL-SS4 ${ }^{\top}$ and recognized Muricauda species

Strains: 1, Muricauda olearia sp. nov. CL-SS4 ${ }^{\mathrm{T}}$ (data from this study); 2, M. aquimarina SW-63 ${ }^{\mathrm{T}}$ (Yoon et al., 2005); 3, M. lutimaris SMK$108^{\mathrm{T}}$ (Yoon et al., 2008); 4, M. ruestringensis DSM $13258^{\mathrm{T}}$ (Yoon et al., 2005); 5, M. flavescens SW-62 ${ }^{\mathrm{T}}$ (Yoon et al., 2005). Fatty acids representing less than $0.5 \%$ in all strains were omitted. All strains were cultivated on MA at $30{ }^{\circ} \mathrm{C}$ for 3 days. ECL, Equivalent chainlength; $\operatorname{tr}$, traces $(<0.5 \%)$; - , not detected/not reported.

\begin{tabular}{|c|c|c|c|c|c|}
\hline Fatty acid & 1 & 2 & 3 & 4 & 5 \\
\hline \multicolumn{6}{|l|}{ Straight-chain } \\
\hline $\mathrm{C}_{15: 0}$ & 10.7 & 5.9 & 7.6 & 13.2 & 12.4 \\
\hline $\mathrm{C}_{16: 0}$ & 0.5 & $\operatorname{tr}$ & $\operatorname{tr}$ & $\operatorname{tr}$ & 0.6 \\
\hline \multicolumn{6}{|l|}{ Branched } \\
\hline iso- $\mathrm{C}_{14: 0}$ & - & 0.6 & - & - & - \\
\hline iso- $\mathrm{C}_{15: 0}$ & 18.7 & 23.7 & 14.5 & 14.7 & 16.4 \\
\hline anteiso- $\mathrm{C}_{15: 0}$ & 1.4 & 2.0 & 1.4 & 1.1 & 2.1 \\
\hline iso- $\mathrm{C}_{15: 1} \mathrm{G}$ & 17.1 & 21.6 & 21.3 & 20.5 & 19.9 \\
\hline iso- $\mathrm{C}_{16: 0}$ & $\operatorname{tr}$ & 0.5 & $\operatorname{tr}$ & - & 0.6 \\
\hline iso- $\mathrm{C}_{17: 1} \omega 9 c$ & 3.6 & 1.5 & 1.8 & 1.4 & 1.3 \\
\hline \multicolumn{6}{|l|}{ Unsaturated } \\
\hline $\mathrm{C}_{15: 1} \omega 6 c$ & 1.4 & 0.9 & 0.6 & 0.9 & 0.9 \\
\hline $\mathrm{C}_{17: 1} \omega 6 c$ & 1.6 & 0.5 & 0.9 & 1.0 & 0.5 \\
\hline $\mathrm{C}_{17: 1} \omega 8 c$ & 0.8 & - & 0.5 & 0.7 & $\operatorname{tr}$ \\
\hline \multicolumn{6}{|l|}{ Hydroxy } \\
\hline $\mathrm{C}_{15: 0} 2-\mathrm{OH}$ & 0.7 & $\operatorname{tr}$ & $\operatorname{tr}$ & 0.5 & 0.6 \\
\hline $\mathrm{C}_{15: 0} 3-\mathrm{OH}$ & 1.9 & 1.4 & 2.6 & 1.8 & 1.0 \\
\hline iso- $\mathrm{C}_{15: 0} 3-\mathrm{OH}$ & 4.4 & 5.2 & 7.8 & 4.6 & 4.7 \\
\hline $\mathrm{C}_{16: 0} 3-\mathrm{OH}$ & 0.9 & 0.6 & 0.5 & $\operatorname{tr}$ & 0.8 \\
\hline iso- $\mathrm{C}_{16: 0} 3-\mathrm{OH}$ & 1.4 & 4.0 & 4.0 & 1.7 & 2.9 \\
\hline $\mathrm{C}_{17: 0} 2-\mathrm{OH}$ & 0.6 & 0.7 & 1.4 & 0.7 & 1.3 \\
\hline $\mathrm{C}_{17: 0} 3-\mathrm{OH}$ & 1.2 & $\operatorname{tr}$ & 0.8 & 1.3 & 0.7 \\
\hline iso- $\mathrm{C}_{17: 0} 3-\mathrm{OH}$ & 20.5 & 17.3 & 24.6 & 20.9 & 19.9 \\
\hline Summed feature $3^{\star}$ & 7.1 & 2.3 & 3.3 & 4.2 & 4.1 \\
\hline \multicolumn{6}{|l|}{ Unknown } \\
\hline ECL 11.543 & - & 0.8 & $\operatorname{tr}$ & 0.6 & - \\
\hline ECL 13.565 & 1.4 & 4.8 & 1.7 & 6.5 & 5.4 \\
\hline ECL 16.582 & 1.5 & 1.3 & 1.9 & 1.7 & 1.6 \\
\hline
\end{tabular}

${ }^{\star}$ Summed feature 3 contains $\mathrm{C}_{16: 1} \omega 7 \mathrm{c}$ and/or iso- $\mathrm{C}_{15: 0} 2-\mathrm{OH}$.

\section{Acknowledgements}

We acknowledge the expert technical support of Ms In-Sung Lee (electron microscopy) of the National Center for Inter-university Research Facilities at Seoul National University. This work was supported in part by the BK21 project of the Korean Government and in part by the research fund of the Mazzeebio Co.

\section{References}

Altschul, S. F., Gish, W., Miller, W., Myers, E. W. \& Lipman, D. J. (1990). Basic local alignment search tool. J Mol Biol 215, 403-410.

Bauer, A. W., Kirby, W. M. M., Sherris, J. C. \& Turck, M. (1966). Antibiotic susceptibility testing by a standardized single disk method. Am J Clin Pathol 45, 493-496.
Bruns, A., Rohde, M. \& Berthe-Corti, L. (2001). Muricauda ruestringensis gen. nov., sp. nov., a facultatively anaerobic, appendaged bacterium from German North Sea intertidal sediment. Int $J$ Syst Evol Microbiol 51, 1997-2006.

Cole, J. R., Chai, B., Farris, R. J., Wang, Q., Kulam-Syed-Mohideen, A. S., McGarrell, D. M., Bandela, A. M., Cardenas, E., Garrity, G. M. \& other authors (2007). The ribosomal database project (RDP-II): introducing $m y R D P$ space and quality controlled public data. Nucleic Acids Res 35, D169-D172.

Collins, M. D. (1985). Analysis of isoprenoid quinones. Methods Microbiol 18, 329-366.

Englen, M. D. \& Kelley, L. C. (2000). A rapid DNA isolation procedure for the identification of Campylobacter jejuni by the polymerase chain reaction. Lett Appl Microbiol 31, 421-426.

Felsenstein, J. (1981). Evolutionary trees from DNA sequences: a maximum likelihood approach. J Mol Evol 17, 368-376.

Fitch, W. M. (1971). Toward defining the course of evolution: minimum change for a specific tree topology. Syst Zool 20, 406-416.

Gosink, J. J., Woese, C. R. \& Staley, J. T. (1998). Polaribacter gen. nov., with three new species, $P$. irgensii sp. nov., $P$. franzmannii sp. nov. and $P$. filamentus sp. nov., gas vacuolate polar marine bacteria of the Cytophaga-Flavobacterium-Bacteroides group and reclassification of 'Flectobacillus glomeratus' as Polaribacter glomeratus comb. nov. Int J Syst Bacteriol 48, 223-235.

Hansen, G. H. \& Sørheim, R. (1991). Improved method for phenotypical characterization of marine bacteria. J Microbiol Methods 13, 231-241.

Jeon, Y.-S., Chung, H., Park, S., Hur, I., Lee, J.-H. \& Chun, J. (2005). jPHYDIT: a JAVA-based integrated environment for molecular phylogeny of ribosomal RNA sequences. Bioinformatics 21, 31713173.

Jukes, T. H. \& Cantor, C. R. (1969). Evolution of protein molecules. In Mammalian Protein Metabolism, vol. 3, pp. 21-132. Edited by H. N. Munro. New York: Academic Press.

Lane, D. J. (1991). 16S/23S rRNA sequencing. In Nucleic Acid Techniques in Bacterial Systematics, pp. 115-175. Edited by E. Stackebrandt \& M. Goodfellow. Chichester: Wiley.

Lemos, M. L., Toranzo, A. E. \& Barja, J. L. (1985). Modified medium for the oxidation-fermentation test in the identification of marine bacteria. Appl Environ Microbiol 49, 1541-1543.

Lyman, J. \& Fleming, R. H. (1940). Composition of sea water. J Mar Res 3, 134-146.

Marmur, J. (1961). A procedure for the isolation of deoxyribonucleic acid from microorganisms. J Mol Biol 3, 208-218.

Mesbah, M., Premachandran, U. \& Whitman, W. B. (1989). Precise measurement of the $\mathrm{G}+\mathrm{C}$ content of deoxyribonucleic acid by highperformance liquid chromatography. Int J Syst Bacteriol 39, 159-167.

Minnikin, D. E., O'Donnell, A. G., Goodfellow, M., Alderson, G., Athalye, M., Schaal, A. \& Parlett, J. H. (1984). An integrated procedure for the extraction of bacterial isoprenoid quinones and polar lipids. J Microbiol Methods 2, 233-241.

Posada, D. \& Crandall, K. A. (1998). MODELTEST: testing the model of DNA substitution. Bioinformatics 14, 817-818.

Rosselló-Mora, R. \& Amann, R. (2001). The species concept for prokaryotes. FEMS Microbiol Rev 25, 39-67.

Saitou, N. \& Nei, M. (1987). The neighbor-joining method: a new method for reconstructing phylogenetic trees. Mol Biol Evol 4, 406-425.

Skerman, V. B. D. (1967). A Guide to the Identification of the Genera of Bacteria, 2nd edn. Baltimore: Williams \& Wilkins.

Smibert, R. M. \& Krieg, N. R. (1994). Phenotypic characterization. In Methods for General and Molecular Bacteriology, pp. 607-654. Edited 
by P. Gerhardt, R. G. E. Murray, W. A. Wood \& N. R. Krieg. Washington, DC: American Society for Microbiology.

Swofford, D. L. (1998). PAUP*: Phylogenetic analysis using parsimony (and other methods), version 4. Sunderland, MA: Sinauer Associates.

Tamura, K., Dudley, J., Nei, M. \& Kumar, S. (2007). MEGA4: Molecular Evolutionary Genetics Analysis (MEGA) software version 4.0. Mol Biol Evol 24, 1596-1599.
Yoon, J.-H., Lee, M.-H., Oh, T.-K. \& Park, Y.-H. (2005). Muricauda flavescens sp. nov. and Muricauda aquimarina sp. nov., isolated from a salt lake near Hwajinpo Beach of the East Sea in Korea, and emended description of the genus Muricauda. Int J Syst Evol Microbiol 55, 1015-1019.

Yoon, J.-H., Kang, S.-J., Jung, Y.-T. \& Oh, T.-K. (2008). Muricauda lutimaris sp. nov., isolated from a tidal flat of the Yellow Sea. Int J Syst Evol Microbiol 58, 1603-1607. 